Мельник Л. В., к.е.н., доцент (Національний університет водного господарства та природокористування, м. Рівне)

\title{
МЕТОДИ УПРАВЛІННЯ РИЗИКАМИ ПРИ ІПОТЕЧНОМУ КРЕДИТУВАННІ АГРАРНОÏ СФЕРИ
}

В статті визначено сутність ризиків іпотечного кредитування аграрної сфери. Виділено особливості ризиків земельно-іпотечного кредитування. Проведено класифікацію ризиків залежно від періодичності їх виникнення. Систематизовано методи управління ризиками іпотечного кредитування залежно від періоду досягнення поставлених цілей. Наголошено на важливості використання методу диверсифікації для мінімізації кредитних ризиків.

Ключові слова: кредитні ризики, земельно-іпотечне кредитування, застава, іпотека, аграрне виробництво.

На фоні реформування аграрного сектору вітчизняної економіки спостерігається значне погіршення фінансового стану та зниження показників прибутковості сільськогосподарських підприємств. Гостра нестача власних фінансових ресурсів у аграрних товаровиробників при одночасному скороченні їх державної підтримки призвела до утворення несприятливого інвестиційного середовища в галузі. Вирішити цю проблему можливо за рахунок залучення кредитних ресурсів під заставу земель сільськогосподарського призначення. Разом з тим, кредитування сільськогосподарських підприємств для комерційних банків на сьогодні $є$ доволі ризиковою операцією. Саме тому, надзвичайно актуальним питанням $€$ питання удосконалення управління кредитними ризиками з метою зменшення їх негативного впливу як на кредитора, так і на позичальника.

Теоретико-методологічні основи управління ризиками при іпотечному кредитуванні розглянуто в працях таких вітчизняних та зарубіжних вчених як О.Є. Гудзь, М. В. Мних, В. О. Безугла, Р. М. Мамчур, А. Х. Кім, М. Я. Головецький, М. А. Однорог, Ф. Найт, Г. Марковіц, К. Редхед та ін. Відзначаючи вагомість наукових праць цих авторів, слід зазначити, що на сьогодні потребує подальшого дослідження понятійний апарат ризиків іпотечного кредитування аграрної сфери.

Метою даного дослідження $є$ узагальнення специфічних рис та особливостей ризиків, з якими стикаються в процесі іпотечного кредитування підприємства аграрної сфери та систематизація методів управління ними. 
Сфера аграрного виробництва $\epsilon$ системою $з$ підвищеним рівнем ризиковості діяльності. Український науковець Холодна Ю.Є. визначає ризик як економічну категорію, що характеризує ймовірність настання події, яка може спричинити фінансові втрати та (або) інші негативні явища [1, С. 122]. Подібним до даного визначення $€$ тлумачення ризику російським економістом Е.О. Андреєвою, яка ототожнює ризик з можливістю втрати частини ресурсів, зниженням запланованих доходів або появою додаткових витрат у результаті здійснення певних фінансових операцій [2, С. 134]. Дещо спрощує сутність ризику А.Ю. Марченко, яка зводить поняття ризику іпотечного кредитування до неповернення у встановлений строк основного боргу та відсотків за позичкою, що належать кредитору [3, С. 236].

Проф. Стецюк П.А., Гудзь О.Є., у дослідженні питання ризикозахищеності підприємства, вважають за доцільне розглядати ризики як економічне явище, пов'язане з подоланням невизначеності, випадковості та конфліктності. Управління ризиком забезпечує стійкість підприємства, здатність протистояти несприятливим ситуаціям і викликам [4, С. 62].

Враховуючи дослідження вчених-економістів, вважаємо, що ризик іпотечного кредитування аграрної сфери може бути визначено, як кількісно виражену (у вартісному або бальному вимірі) ймовірність виникнення події в результаті прийняття певних управлінських рішень, наслідками якої можуть бути як отримання додаткових вигод (у вигляді прибутків, пільг, благ), так і понесення додаткових витрат.

3 точки зору значущості ризики іпотечного кредитування вітчизняні науковці поділяють на основні (кредитний, ринковий, процентний, ризик ліквідності, валютний) та додаткові (операційнотехнічний, форс-мажорний, політичний, адміністративний тощо). І якщо в питаннях поділу ризиків прослідковується єдиний підхід, то в питаннях класифікації ризиків думки вчених істотно розрізняються залежно від критеріїв класифікації. Так, Ващик М.С. до видів кредитних ризиків сільськогосподарських підприємств відносить наступні :

- зміна кредитної політики комерційного банку;

- погіршення результатів господарювання через природнокліматичні умови;

- підвищення банківської процентної ставки та комісійних платежів;

- погіршення фінансового стану підприємства;

- неодержання бюджетної компенсації при пільговому кредиті;

- дефіцит ліквідних гарантій;

- зміни в законодавстві та державній політиці; 

C. 336].

- низька якість об'єкта застави, зниження їі ліквідності [5,

Проте дана класифікація носить доволі узагальнений характер та не розкриває особливостей ризиків іпотечного кредитування аграрної сфери. Крім того, в ній не виокремлено критерії, за якими кредитні ризики розподілено на ті чи інші види.

Нам імпонує точка зору Ю.В. Груздєва, який виділяє п'ять груп ризиків, що виникають в процесі іпотечного кредитування сільгоспвиробників [6, С. 255]. Зокрема:

- перша група ризиків пов'язана з відсутністю ринку земель сільськогосподарського призначення. Це призводить до того, що взяти кредит в банку можуть лише фінансово стійкі підприємства, оскільки в іншому випадку в банку можуть виникнути труднощі з реалізацією застави, адже не визначено чіткої процедури реалізації земельних ділянок;

- друга група ризиків пов'язана з недостатньою підтримкою іпотечного кредитування зі сторони держави: відсутній економікоправовий механізм викупу земельних ділянок, що перебувають в заставі, не проводиться підтримка фінансовими ресурсами сільськогосподарських виробників щодо відшкодування витрат на сплату відсотків за кредитом тощо;

- третя група ризиків пов'язана з усуненням страхових й оціночних компаній з ринку кредитних операцій як активних суб'єктів цього ринку та відведення їм ролі уповноважених посередників;

- четверта група ризиків пов'язана з відсутністю державного регіонального земельного фонду, діяльність якого повинна будуватися на принципах господарської самостійності та регламентуватися законодавством;

- п'ята група ризиків пов'язана із сезонним характером сільськогосподарського виробництва, завдяки чому реалізувати земельну ділянку у разі неповернення кредиту заставодавцем можливо тільки після повного збору врожаю.

Ризики, що виникають у процесі залучення інвестицій у сільське господарство шляхом іпотечного кредитування, є об'ємними: з одного боку має вагоме значення висока залежність результатів діяльності від природно-кліматичних умов та від структурних змін у споживчій кон'юнктурі внутрішнього та зовнішнього ринків. Основними ризиками, які виникають під час вирощування сільськогосподарських культур та багаторічних насаджень є: посуха (47\%), вимерзання (35\%) та пожежа (11\%); у тваринництві основним ризиком є падіж худоби через епідемії та надзвичайні ситуації природного, техногенного, воєнного характеру [7, С. 127]. 
3 іншого ж боку ризики, притаманні іпотечному кредиту як банківському продукту, до яких переважно відносяться ризики кредитора та інвестора. Спираючись на дослідження Н. В. Грищук, зазначимо, що до числа останніх належать ризики, умовно віднесені до трьох груп: систематичні (нестабільність державної політики щодо регулювання аграрних ринків, коливання цін на сільськогосподарську продукцію), несистематичні та випадкові [8, С. 10]. Беручи до уваги праці А. Г. Івасенка, Н.В.Грищук, А. Х. Кіма та Ю. Є. Холодної [110], до несистематичних ризиків віднесемо:

1) ризики, вплив яких можна мінімізувати:

- ризик реінвестування (дострокового погашення);

- майновий ризик;

2) ризики, вплив яких неможливо повністю мінімізувати:

- кредитний ризик (ризик неповернення позики);

- ризик відсоткової ставки;

- валютний ризик;

- ризик ринкової ліквідності;

- ризик альтернативного вибору;

- ризик зміни доходу на акціонерний капітал;

- ризик події;

- операційний ризик.

Передумовою виникнення ризику в процесі іпотечного кредитування аграрної сфери завжди $€$ значний часовий проміжок між точкою капіталовкладення та точкою випуску і реалізації сільськогосподарської продукції, причому збільшення такого часового лагу лише посилює ринкові ризики [9, С. 111].

Використання системи управління ризиками діяльності зумовлено необхідністю суб'єктів економічних відносин реалізовувати свій виробничий і ресурсний потенціал, мінімізуючи вплив негативних факторів. В зарубіжній та вітчизняній практиці існує безліч методів та інструментів, що формують систему управління ризиками, динамічне використання яких з урахуванням економічного становища, сильних і слабких сторін суб'єктів господарювання, а також національних особливостей розвитку галузей економіки дає позитивний ефект, мінімізуючи збитки і, часто, максимізуючи прибутки.

Врахування різних підходів вчених до ідентифікації сутності процесу управління ризиками, дає нам змогу систематизувати сукупність методів управління ризиками в процесі інвестиційної діяльності залежно від періоду, в якому планується досягнення поставлених цілей:

1) тактичні методи:

- забезпечення високої ліквідності інвестицій. Цей метод пе- 
редбачає оцінку рівня ліквідності активів, що є предметом інвестиційних відносин, визначення величини ринкового попиту на дані активи з метою виявлення резервних варіантів покриття збитків за рахунок реалізації активів поза інвестиційним проектом внаслідок невдачі останнього;

- лімітування витрат, що передбачає встановлення граничних розмірів витрат, здійснення операцій з реалізації, кредитних операцій тощо. Лімітування витрат реалізується шляхом впровадження системи фінансових нормативів за певними напрямами інвестиційної діяльності, перевищення яких $є$ недопустимим, і $є$ ефективним методом зменшення ступеню ризику;

- хеджування, інакше кажучи, використання механізму оперування деривативами на вторинному ринку цінних паперів. Сутність хеджування полягає у зниженні ризиків наступних втрат від здійснення майбутніх угод шляхом здійснення операцій з реалізації і придбання похідних цінних паперів - опціонів або ф'ючерсів - залежно від обраної політики: хеджування на підвищення (купівля деривативів) або хеджування на пониження (продаж деривативів). Хеджер, тобто суб'єкт господарювання, що здійснює операції хеджування, за результатами угоди заключає контракт на страхування від ризиків виникнення курсових коливань, що має назву хедж;

- здійснення оперативного моніторингу інформаційного поля на предмет актуальної ситуації у сфері законодавства, становища контрагентів, кон'юнктури на ринку нерухомості, фондовому ринку тощо;

- поділ інвестиційного проекту на окремі частини в часі з метою зменшення витрат на реалізацію кожного окремого етапу шляхом їх почергового, поступового впровадження у промислову експлуатацію. Така поетапна реалізація інвестиційного проекту дає змогу не лише раціонально використовувати фінансові ресурси, а й здійснювати діагностику поступово, з можливістю виявлення «вузьких місць» на ранніх етапах впровадження проекту в реальному середовищі, тобто здійснювати так звану «обережну» тактику;

2) стратегічні методи:

- застосування політики уникнення ризиків, основною метою якої $\epsilon$ абсолютне виключення окремого типу ризиків інвестування шляхом складання відповідної програми заходів із запобігання можливості виникнення таких ризиків. За такої політики суб'єкт господарювання, перш за все, здійснює оцінку і ранжування сукупності можливих операцій, необхідних для реалізації проекту, за ступенем ризиковості. В подальшому операції, що опинились в групі з високим ризиком, як правило, виключаються з процесу; 
- андерайтинг - метод поліаспектної оцінки імовірності настання кредитного ризику на предмет платоспроможності, кредитоспроможності та добропорядності позичальника. Даний метод охоплює чотири послідовних етапи оцінки відповідності позичальника за встановленими критеріями: попередній відбір потенційних позичальників, формування інформаційної бази щодо фінансового стану та репутації потенційного позичальника, оцінка платоспроможності, кредитоспроможності та здатності позичальника покриття початкового внеску та витрат на укладання угоди, аналіз факторів ризику та прийняття рішення;

- формування внутрішніх страхових резервів, метою яких $\epsilon$ покриття ризикового капіталу. Серед таких резервів вчені виділяють резервний фонд, залишок нерозподіленого прибутку, спеціалізовані резервні фонди тощо;

- диверсифікація, що полягає у мінімізації ризиків інвестування шляхом розподілу інвестиційних ресурсів між різними проектами, об'єктами інвестування, непов'язаних між собою. Можливе також застосування диверсифікації в межах одного проекту за рахунок орієнтації на різні категорії споживачів, регіональної диверсифікації, диверсифікації залучених ресурсів тощо;

- реалізація державних гарантій захисту від конкретного типу ризиків (функціонування державних фондів гарантування інвестицій, законодавче закріплення державних гарантій страхування інвестиційних ризиків фізичних та юридичних осіб);

- метод страхування фінансових ризиків, сутність якого полягає у створенні страховиком за рахунок платежів страхувальника спеціалізованого резервного (страхового) фонду з метою покриття збитків у разі настання страхового випадку (внаслідок надзвичайних ситуацій або з інших причин). Страхування $є$ окремою сферою економічних відносин, визначальним фактором яких $€$ те, що страхувальник, тобто інвестор, заради зниження величини ризику готовий відмовитись від частини доходу (страхові платежі). Вітчизняна практика свідчить про те, що в процесі кредитування під заставу нерухомості здійснюється, як правило, один вид страхування - страхування застави;

- розподіл ризиків шляхом їх часткової передачі контрагентам, що є учасниками ризикових операцій, залежно від їх функціональних обов'язків.

Якщо ж говорити конкретно про ресурсний потенціал іпотечного кредитування в аграрній сфері як про фінансово-інвестиційну систему, то в цій області недостатньо було проведено досліджень щодо 
впливу комплексних заходів з управління ризиками на розширення та ефективність використання власне ресурсного потенціалу земельно-іпотечного кредитування.

Підводячи підсумок, слід зазначити, що з огляду на багатокомпонентність поняття ресурсного потенціалу іпотечного кредитування сільського господарства, на нашу думку, найбільш доцільними для використання методами управління ризиками в даній сфері $€$ диверсифікація. Як вказує 0. О. Томілін, диверсифікацію в аграрному секторі економіки застосовують з метою: зменшення ризиків; розширення номенклатури продукції; збільшення дохідності підприємства; освоєння нових технологій та напрямків виробництва; забезпечення більшої стабільності результатів та уникнення коливань в одержанні прибутку тощо [10, С. 208].

Передумовою виникнення необхідності застосування диверсифікації в процесі формування заставного потенціалу іпотечного кредитування $€$ існування іпотечних ризиків кредитора (ризики реінвестування, ліквідності, майнові, відсоткові, кредитні) та потреба у їх мінімізації з метою провадження ефективної господарської діяльності у довгостроковій перспективі. І хоча надання фінансових ресурсів під заставу нерухомого майна є одним із надійних шляхів кредитування, проте воно не здатне забезпечити повну впевненість кредитора у захищеності від непередбачуваних подій.

Ураховуючи все вище сказане, слід зазначити, що питання диверсифікації кредитних ризиків іпотечного кредитування аграрної сфери, як найбільш дієвого та, водночас, простого методу управління кредитними ризиками, потребує подальшого вивчення та дослідження.

1. Холодна Ю. Є. Мінімізація ризиків іпотечного кредитування в сучасних умовах. Науковий вісник Херсонського державного університету. 2016. Вип. 17, 4. 4. С. 122-126. 2. Андреева Э. А. Проблемы анализа и оценки рисков инвестиционных проектов. Вестник Саратовского Государственного Технического университета. 2008. № 4 (36). С. 133-137. 3. Марченко А. Ю. Ризики іпотечного кредитування та особливості їх прояву в Україні. Проблеми і перспективи розвитку банківської системи України : зб. наук. праць. Суми : УАБС НБУ, 2007. Вип. 20. С. 234-243. 4. Стецюк П. А. Концептуальні основи управління ризикозахищеністю підприємства. Економіка АПК. 2014. № 11. С. 61-68. URL: http://nbuv.gov.ua/UJRN/E_apk_2014_11_11. (дата звернення: 15.01.2019). 5. Ващик М. С. Кредитні ризики сільськогосподарських підприємств та можливості їх мінімізації. Інноваційна економіка. 2013. № 2. С. 334337. 6. Груздєв Ю. В. Проблеми розвитку земельно-іпотечного кредитування сільського господарства України. Сталий розвиток економіки. 2014. № 3. С. 253-258. 7. Мамчур Р. М. Управління ризиками в сільському господарст- 
ві. Науковий вісник Національного університету біоресурсів і природокористування України. Економіка, аграрний менеджмент, бізнес. 2013. Вип. 181(5). С. $125-129$.

URL:

http://nbuv.gov.ua/UJRN/nvnau_econ_2013_ 181\%285\%29_21 (дата звернення: 15.01.2019). 8. Грищук Н. В. Іпотечне кредитування: проблеми та перспективи розвитку в Україні. Інформаційноаналітичні матеріали. К. : Центр наукових досліджень НБУ, 2004. С. 9-10. 9. Однорог М. А. Особливості інвестиційної діяльності в аграрному секторі. Актуальні проблеми міжнародних відносин. 2015. Вип. 126 (Ч. ІІ). С. 108-115. 10. Томілін 0. О. Диверсифікація аграрних підприємств як дієва стратегічна орієнтація в агропромисловій сфері. Збірник наукових праць ВНАУ. Економічні науки. 2012. № 3(69). С. 205-211.

\section{REFERENCES:}

1. Kholodna Yu. Ye. Minimizatsiia ryzykiv ipotechnoho kredytuvannia v suchasnykh umovakh. Naukovyi visnyk Khersonskoho derzhavnoho universytetu. 2016. Vyp. 17, Ch. 4. S. 122-126. 2. Andreeva E. A. Problemy analiza i otsenki riskov investitsionnykh proektov. Vestnyk Saratovskoho Hosudarstvennoho Tekhnycheskoho unyversyteta. 2008. № 4 (36). S. 133-137. 3. Marchenko A. Yu. Ryzyky ipotechnoho kredytuvannia ta osoblyvosti yikh proiavu $\vee$ Ukraini. Problemy i perspektyvy rozvytku bankivskoi systemy Ukrainy : zb. nauk. prats. Sumy : UABS NBU, 2007. Vyp. 20. C. 234-243. 4. Stetsiuk P. A. Kontseptualni osnovy upravlinnia ryzykozakhyshchenistiu pidpryiemstva. Ekonomika APK. 2014. № 11. S. 61-68. URL: http://nbuv.gov.ua/UJRN/E_apk_2014_11_11. (data zvernennia: 15.01.2019). 5. Vashchyk M. S. Kredytni ryzyky silskohospodarskykh pidpryiemstv ta mozhlyvosti yikh minimizatsii. Innovatsiina ekonomika. 2013. № 2. S. 334-337. 6. Hruzdiev Yu. V. Problemy rozvytku zemelno-ipotechnoho kredytuvannia silskoho hospodarstva Ukrainy. Stalyi rozvytok ekonomiky. 2014. № 3. S. 253-258. 7. Mamchur R. M. Upravlinnia ryzykamy $v$ silskomu hospodarstvi. Naukovyi visnyk NatsionaInoho universytetu bioresursiv i pryrodokorystuvannia Ukrainy. Ekonomika, ahrarnyi menedzhment, biznes. 2013. Vyp. 181(5). S. 125-129. URL: http://nbuv.gov.ua/UJRN/nvnau_econ_2013_181\%285\%29_21 (data zvernennia: 15.01.2019). 8. Hryshchuk N. V. Ipotechne kredytuvannia: problemy ta pe-rspektyvy rozvytku v Ukraini. Informatsiino-analitychni materialy. K. : Tsentr naukovykh doslidzhen NBU, 2004. S. 9-10. 9. Odnoroh M. A. Osoblyvosti investytsiinoi diialnosti $v$ ahrarnomu sektori. Aktualni problemy mizhnarodnykh vidnosyn. 2015. Vyp. 126 (Ch. II). S. 108-115. 10. Tomilin 0. 0. Dyversyfikatsiia ahrarnykh pidpryiemstv yak diieva stratehichna oriientatsiia $v$ ahropromyslovii sferi. Zbirnyk naukovykh prats VNAU. Ekonomichni nauky. 2012. № 3(69). S. 205211.

Рецензент: д.е.н., професор Савіна Н. Б. (НУВГП) 
Melnyk L. V., Candidate of Economics (Ph.D.), Associate Professor (National University of Water and Environmental Engineering, Rivne)

\section{METHODS OF RISK MANAGEMENT IN MORTGAGE LENDING AGRICULTURAL SPHERE}

The purpose of this study is to generalize the specific features and peculiarities of the risks encountered in the process of mortgage lending of agricultural enterprises and systematization of their management methods.

The risk of mortgage lending in the agrarian sector can be defined as the quantified probability of occurrence of the event as a result of the adoption of certain managerial decisions, the consequences of which can be both obtaining additional benefits, and incurred additional costs.

The risks of mortgage lending in the period of their occurrence are divided into systematic: the instability of the state policy on the regulation of agrarian markets, fluctuations in prices for agricultural products; unsystematic and random.

The methods of risk management include tactical and strategic methods. Tactical methods include: ensuring high liquidity of investments, limiting the cost of a credit operation, hedging, conducting an operational monitoring of the information field, splitting the investment project into separate parts in time in order to reduce the costs of implementing each individual stage. Strategic methods include: application of risk avoidance policies; underwriting; formation of internal insurance reserves in order to cover risk capital; diversification, which is to minimize risks by allocating investment resources between different projects; realization of state guarantees of protection against a specific type of risk; method of insurance of financial risks.

The most expedient way to use risk management in mortgage lending in the agrarian sector has been diversification.

Keywords: credit risks, land mortgage lending, mortgage, mortgage, agrarian production. 
Мельник Л. В., к.э.н., доцент (Национальный университет водного хозяйства и природопользования, г. Ровно)

\section{МЕТОДЫ УПРАВЛЕНИЯ РИСКАМИ ПРИ ИПОТЕЧНОМ КРЕДИТОВАНИИ АГРАРНОЙ СФЕРЫ}

В статье определена сущность рисков ипотечного кредитования аграрной сферы. Выделены особенности рисков земельноипотечного кредитования. Проведена классификация рисков в зависимости от периодичности их возникновения. Систематизированы методы управления рисками ипотечного кредитования в зависимости от периода достижения поставленных целей. Подчеркнута важность использования метода диверсификации для минимизации кредитных рисков.

Ключевые слова: кредитные риски, земельно-ипотечное кредитование, залог, ипотека, аграрное производство. 